\title{
Gonadotropic cells of the rainbow trout pituitary during the annual cycle. Ultrastructure and hormone content.
}

\author{
par J. PEUTE, H. J. Th. GOOS, Marielle G. A. DE BRUYN, P. G. W. J. VAN OORDT \\ Zoological Laboratory, Section Comparative Endocrinology \\ University of Utrecht, Padualaan 8, Utrecht, The Netheriands.
}

\begin{abstract}
Summary. The GTH cells in the rainbow trout Salmo gairdneri appeared in a « globular » or in a « cisternal » stage with intermediates. Most GTH cells in females were in the globular stage up to June, after which predominately cisternal ones were observed for about 2 months. A similar shift was seen in male GTH cells in September. Correlation between RIA and ultrastructural studies of the pituitary suggested the storage of GTH in secretory vesicles and globules. The drop in pituifary hormone content was concomitant with the onset of exogenous vitellogenesis in June/July and with the acceleration of spermiogenesis in September. Both processes appeared to be GTH-dependent.
\end{abstract}

\section{Introduction.}

The salmonid pituitary produces a gonadotropic hormone (GTH) inducing spermatogenesis and vitellogenesis in goldfish (Yamazaki and Donaldson, 1968). The plasma concentration of this hormone increases during sexual maturation (Crim ef al., 1975). The pituitary cells producing GTH simultaneously increase in number and secretory activity (Olivereau and Ridgway, 1962 ; Van Overbeeke and McBride, 1967). It is assumed that quantitative changes in plasma and pituitary GTH correspond with changes in the ultrastructure of the GTH cells. The validity of this assumption has been tested by studying the hormone content and the ultrastucture of rainbow trout GTH cells at various stages of the reproductive cycle. The gonadotropic nature of these cells was determined by means of histophysiological and immunohistochemical studies by Boddingius (1975) and Goos (unpublished results), respectively. As in other salmonids such as Salmo salar (Ekengren ef al., 1978), the gonadotropic cells in the rainbow trout pituitary were basophils, situated in the rostral as well as in the proximal pars distalis ; depending on the physiological state of the animal, the cells contained both secretory vesicles and globules.

\section{Material and methods.}

Animals. - At intervals of one or two months, pituitaries were collected from three male and three female Salmo gairdneri, reared in a Dutch hatchery. The ani- 
mals logether cover one annual cycle (1975/1976). Prior to decapitation the animals were anaesthetized with $\mathrm{Ms} 222$ or $\mathrm{CO}_{2}$.

Electron microscopy. - The method of Peute et al. (1976) was used.

Radioimmunoassay. - Pituitaries were extracted in $200 \mu$ l of phosphate buffered saline (0.01 M, pH 7.2). A heferologous radioimmunoassay system was used for measuring pituitary GTH content. With this system, all data from the assay have to be considered as relative values. Therefore, the amount of GTH detected in pituitary extracts is expressed in assay units (AU) instead of weight units.

Antiserum was raised against salmon gonadotropin (SG-G100 from Dr. E. Donaldson-Vancouver) and used at a working dilution of $1: 32000$, which means in this assay a final dilution of $1: 180000$. Maximal B/F ratio with this dilution was 0.2 .

According to the chloramine-T method ${ }^{125}$ jodine-labeled pure carp gonadotropin (from Dr. E. Burzawa-Gérard-Paris) was used as label (500 cpm/tube. The same carp-GTH has been applied as standard hormone in a range of $12.5 \mathrm{pg} /$ tube to $0.5 \mathrm{ng} /$ tube. Assay sensitivity was defined as the lowest detectable amount of hormone (about $1.4 \mathrm{AU} / \mathrm{ml}$ ).

\section{Observations.}

\section{Electron microscopy.}

During the greater part of the year, most GTH cells in males and females are characterized by the combined presence of globules, measuring 4000-8000 $\AA$ In diameter, and round to oval or somewhat elongate secretory vesicles, $1000-3000 \AA$ In diameter. The cells contain small, rounded cisternae of rough endoplasmic reticulum (RER, fig. 1). These represent the so-called « globular » stage, and are mainly situated in the proximal pars distalis. In addition, GTH-cells can also be observed between the follicles of the rostral pars distalis and among the prolactin cells as part of the follicles (fig. 2). During some months, however, the majority of GTH-cells are in the so-called « cisternal » stage. Globules and secretory vesicles have almost. completely disappeared and the cytoplasm is mainly composed of numerous more or less round and dilated cisternae, the membranes of which are studded with a few ribosomes (fig. 3). The cisternae contain material of moderate electron density. Intermediate stages have also been noticed, i. e. cisternal cells with few or no globules, but with active Golgi systems budding secretory vesicles. Depending on the time of the year,

FIG. 1. - Proximal pars distalis ; GTH cells in " globular » stage. SC : stellate cell ( $\times 5$ 000).

FIG. 2. - Rostral pars distalis ; "globular 》 GTH cell in a follicle of prolactin cells. L : lumen $(\times 5000)$.

FIG. 3. - Proximal pars distalis ; GTH cells in «cisternal " stage. GA : Golgi area ; SC : stellate cell, STH somatotrop $(\times 5000)$. 

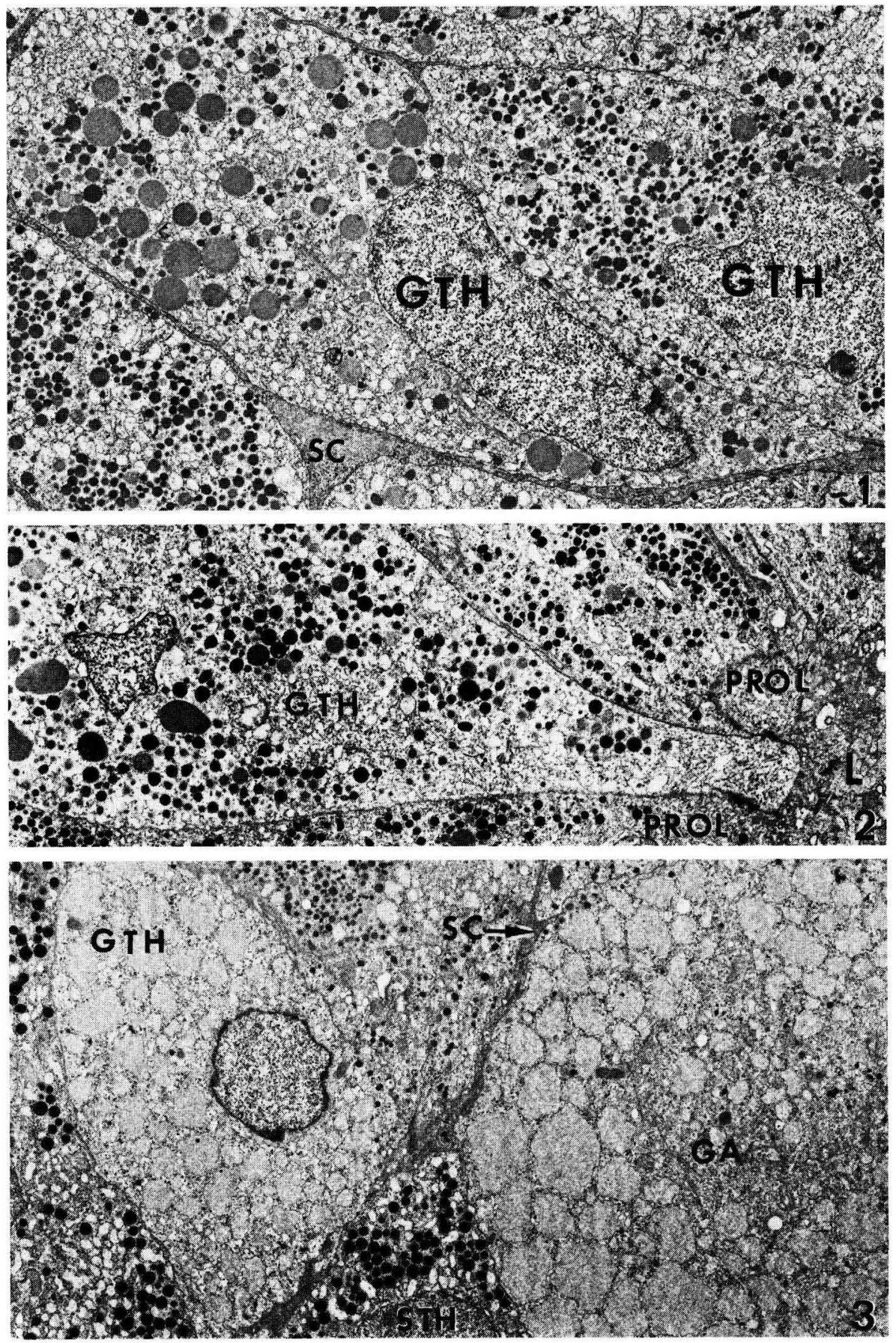
both the globular and the cisternal stages as well as intermediate forms may be found within one and the same pituitary. In female trout a predominantly cisternal stage is reached in June and lasts about until October. Then a gradual regranulation takes place, and in December more cells containing secretory vesicles and globules can be observed. This shift to the globular stage continues from January to March ; later, GTH-cells are hardly present in the cisternal stage.

In males the cisternal stage was much shorter, i. e. from September to November. Then a gradual regranulation of many GTH-cells was observed, leading to a heterogeneous population of GTH-cells in which the globular stage finally predominates. In this period some GTH-cells contain one or two large cisternae, which almost completely fill up the cytoplasm. Such cells have no globules and only a few secretory vesicles. Between March and May the cisternal stage gradually disappears and the globular stage predominates up to September.

\section{Radioimmunoassay.}

The pituitary of females collected during June and July contains an average of $2000 \mathrm{AU}$. This increased to $20000 \mathrm{AU}$ in August, to $30000 \mathrm{AU}$ in November and to $100000 \mathrm{AU}$ in December. The GTH content remained high up to April-May.

In pituitaries of males, low values (4000 AU) were not found until September ; thereafter the values increased again to $100000 \mathrm{AU}$, and in some animals even to $200000 \mathrm{AU}$ by December. Such high values continued to be present up to August. In August the GTH content dropped to about 20000 AU per pituitary, and this decrease continued until September.

\section{Discussion.}

From a comparison of the present ultrastructural observations with the results of the RIA method, it may be concluded that there is generally a correlation befween the presence of the globular stage of the GTH-cells and a high titer of GTH assay units. Low levels of GTH coincide with predominantly cisternal GTH-cells. This means that both the secretory vesicles and the globules probably represent the storage organelles of the gonadotropin principle (see also Nagahama and Yamamoto, 1969).

This would make it unlikely that in Salmo gairdneri the globules of the GTH-cells represent lysosomes, as suggested for other species by Olivereau (1967), Ball and Baker (1969) and others. Indeed, it has not been possible to detect the important lysosomic enzyme, acid phosphatase, in the globules of trout GTH-cells. However, in addition to the globules, round organelles resembling lysosomes have occasionally been observed ultrastructurally (Peute, unpublished results). The drop in GTH content, and the disappearance of secretory vesicles and globules in the GTH-cells of the females during June and July, coincide with an augmentation in steroidogenic capacity of the ovary and also of exogenous vitellogenesis in the oocytes (Lambert et al., 1978). A similar correlation can be made in male trout during September-October, when germ cell maturation and spermiogenesis are accelerated (Van den Hurk et al., 1978). Thus in Salmo gairdneri both vitellogenesis and the formation of sperm cells can be correlated with a decreased pituitary GTH content. 
In other salmonids these gonadal processes were accompanied by an increased blood GTH level (Crim et al., 1975).

On the other hand, the high steroidogenic activity in the post-ovulatory follicles (Lambert et al., 1978) and in the testicular Leydig cells (Van den Hurk ef al., 1978) during January-February is not concomitant with a decrease in GTH storage in the pituitary. This does not exclude a marked GTH release during that part of the year. Indeed, Goos (unpublished) recorded a high GTH level in the blood of female Salmo gairdneri in January-February. In the same period, GTH-cells with extremely large cisternae have been observed in the pituitary of male trouts. Such large cisternae have been interpreted by Kaul and Vollrath, (1974) and by Lam et al. (1976) as the resul of a high secretory activity.

The present results indicate that changes in storage of secretory vesicles and globules can be related to changes in the pituitary GTH content, but do not necessarily reflect variations in GTH release. In the present study it is demonstrated that during the annual cycle the GTH-cells pass through different phases of activity, which are not synchronous in all GTH-cells. The result is a mixed population, its composition depending on the sex of the animal and the time of the year.

These data do not justify the assumption that there is more than one type of GTHcells in the pituitary of Salmo gairdneri. Similarly, Nagahama (1973) and Ekengren ef al. (1978) found only one GTH-cell type in salmonids, whereas Cook and Van Overbeeke (1972) and Olivereau (1976) defended the presence of two GTH-cell types in the pituitary of this. group of teleosts.

Symposium sur la Reproduction des Poissons Paimpont. France, 19-21 septembre 1977.

Résumé. Les cellules gonadotropes chez la Truite Salmo gairdneri peuvent apparaître sous deux états « globulaire » ou « citernal » (avec des intermédiaires). Chez la femelle, la plupart des cellules gonadotropes sont de type « globulaire » jusqu'en juin, puis « citernal » pendant environ 2 mois. Le même changement est observé chez le mâle en septembre. La comparaison de ces résultats avec ceux obtenus par dosage de la gonadotropine (GTH) dans l'hypophyse et études de l'ultrastructure hypophysaire suggère que la GTH est stockée dans des vésicules sécrétoires et des globules. Une corrélation a également été mise en évidence entre la chute de la teneur hypophysaire en GTH et le début de la vitellogenèse exogène (juin/juillet) et l'accélération de la spermiogenèse (septembre). Les deux processus semblent sous la dépendance de la GTH.

\section{References}

BALL J. N., BAKER B. J., 1969. The pituitary gland: anatomy and histophysiology, 1-110. In HOAR W. S., RANDALL D. J., Fish Physiology, vol. II, Acad. Press, N. Y., London.

BODDINGIUS J., 1975. The cell types of the adenohypophysis in the roinbow trout (Salmo irideus) ; A histological study. Thesis Univ. Groningen, Holywell Press Lid. Oxford.

COOK H., OVERBEEKE A. P. VAN, 1972. Ultrastructure of the pituitary gland (pars distalis) in Sokeye Salmon (Oncorhynchus nerka) during gonad maturation. Z. Zellforsch, 130, 338-350.

CRIM L. W., WATTS E. G., EVANS D. M., 1975. The plasma gonadotropin during sexual maturation, in a variety of salmonid fishes. Gen. comp. Endocr., 27, 62-70.

EKENGREN B., PEUTE J., FRIDBERG G., 1978. The distribution and nature of gonadotropic cells in the rostral pars distalis of the Atlantic salmon, Salmo salar. Ann. Biol. anim. Bioch. Biophys., 18, 799-804. 
HURK R. VAN DEN, VERMEIJ J. A. J., STEGENGA J., OORDT P. G. W. J. VAN, 1978. Cyclic changes in the festis and vas deferens of the rainbow trout, Salmo gairdneri, with special reference to sites of steroidogenesis. Ann. Biol. onim. Bioch. Biophys., 18, 899-904.

KAUL S., VOLLRATH L., 1974. The goldfish pituitary. I. Cytology. Cell Tiss. Res., 154, 211-230.

LAM T. J., PANDEY S., NAGAHAMA Y., HOAR W. S., 1976. Effect of synthetic luteinizing hormonereleasing hormone (LH-RH) on ovulation and pituitary cytology in the goldfish, Carassius ouratus. Conad. J. Zool., 54, 816-824.

LAMBERT J. G. D., BOSMAN G. I. C. G. M., HURK R. van den, OORDT P. G. W. J. van, 1978. Annual cycles of plasma cestradiol-17 $\beta$ in the female trout, Salmo gairdneri. Ann. Biol. anim. Bioch. Biophys., 18, 923-927.

NAGAHAMA Y., 1973. Histo-physiological studies on the pituitary gland of some teleost fishes with special reference to the classification of hormone-producing cells in the adenohypophysis. Mem. Fac. Fish., Hokkaido, Univ., 21, 1-63.

NAGAHAMA Y., YAMAMOTO K., 1969. Basophils in the adenohypophysis of the goldfish (Carassius ourafus), Gunma Symp. Endocrinol., 6, 39-55.

OLIVEREAU M., 1967. Observations sur l'hypophyse de l'anguille femelle, en particulier lors de la maturation sexuelle. $Z$. Zellforsch., 80, 286-306.

OLIVEREAU M., 1976. Les cellules gonadotropes hypophysaires du saumon de l'Aflantique : unicité ou dualité ? Gen. comp. Endocr., 28, 82-95.

OLIVEREAU M., RIDGWAY G. J., 1962. Cyłologie hypophysaire ef antigène sérique en relation avec la maturation sexuelle chez Oncorhynchus species. C. R. Acad. Sci. Paris, 254, 753-755.

OVERBEEKE A. P. van, McBRIDE J. R., 1967. The pituitary gland of the sockeye (Oncorhynchus nerka) during sexual maturation and spawning. J. Fish. Res. Bd. Con., 24, 1791-1810.

PEUTE J., BRUYN M. G. A. de, SELDENRIJK R., OORDT P. G. W. J. van, 1976. Cytophysiology and innervation of gonadotropic cells in the pituitary of the black molly (Poecila latipinna). Cell Tiss. Res., 174, 35-54.

YAMAZAKI F., DONALDSON E. M., 1968. The effects of partially purified salmon pituitary gonadotropin on spermatogenesis, vitellogenesis and ovulation in hypophysectomized goldfish (Carassius auratus). Gen. comp. Endocr., 11, 292-299. 